Article

\title{
Distribution Patterns of Burned Areas in the Brazilian Biomes: An Analysis Based on Satellite Data for the 2002-2010 Period
}

\author{
Fernando Moreira de Araújo *, Laerte Guimarães Ferreira and Arielle Elias Arantes \\ Image Processing and GIS Lab/UFG-IESA, Federal University of Goiás, Campus Samambaia, Cx. \\ Postal 131, Goiânia-GO, 74001-970, Brazil; E-Mails: laerte@iesa.ufg.br (L.G.F.); \\ arielle_ioiad@hotmail.com (A.E.A.)
}

* Author to whom correspondence should be addressed; E-Mail: fernandomsbl@ gmail.com; Tel.: +55-62-3521-1096; Fax: +55-62-3521-1077.

Received: 20 May 2012; in revised form: 19 June 2012 / Accepted: 21 June 2012 /

Published: 29 June 2012

\begin{abstract}
Fires modify the structure of vegetation communities, the carbon and water cycles, the soil's chemistry, and affect the climate system. Within this context, this work aimed to understand the distribution patterns of burned areas in Brazil, during the period of 2002 to 2010, taking into consideration each one of the six Brazilian biomes (Amazon, Caatinga, Cerrado, Atlantic Forest, Pampa and Pantanal) and the respective major land cover classes. Data from the MODIS MCD45A1 product (burned area), as well as thermal anomalies (MOD14 and MYD14) and precipitation (TRMM), were analyzed according to the 2002 Brazilian official land cover and land use map (PROBIO). The Brazilian savanna biome, known as Cerrado, presented the largest concentration of burned areas detected by MODIS (73\%), followed by the Amazon (14\%), Pantanal (6\%), Atlantic Forest (4\%), Caatinga (3\%), and Pampa (0,06\%) biomes. Indeed, in the years of 2007 and 2010, 90\% and $92 \%$ of Brazil's burned areas were concentrated in the Cerrado and Amazon biomes, respectively. TRMM data indicated that during these two years there was a significant influence of La Niña, causing low rainfall in the Amazon, Cerrado, Caatinga, and Atlantic Forest biomes. Regarding the land cover classes, approximately $81 \%$ of the burned areas occurred over remnant vegetation areas. Although no unequivocal correlation can be established between burned areas and new land conversions, the conspicuous concentration of fire scars, particularly in Amazon-Cerrado transition (i.e., the Arc of Deforestation) is certainly not a simple coincidence. Such patterns and trends corroborate the need of improved territorial governance, in addition to the implementation of systematic fire warning and preventive systems.
\end{abstract}


Keywords: burned areas; Brazilian biomes; MCD45A1; land cover change

\section{Introduction}

Fires, generally of anthropogenic origin, affect the distribution of global ecosystems by modifying the structure of vegetation communities and interfering with the reproduction and survival mechanisms of living species. Moreover, burns disturb the soil's chemistry, the carbon and water cycles, as well as the climate system through the release of greenhouse gases [1,2]. According to van der Werf et al. [3] and Bowman et al. [4], during the period of 1997 to 2001, about two thirds of the emitted atmospheric CO2 and aerosols anomalies can be attributed to the increase in fire activity during the 1997 and 1998 El Nino years.

The rise of these gases, particularly $\mathrm{CO}_{2}$, can induce stomatal closure, decreasing the transpiration of the canopy and the latent heat flow of the landscape [5]. Also, the increase in the concentration of aerosols from fires reduces the amount of solar radiation that reaches the surface, in a process called solar-dimming, reducing pan evaporation [6]. Indeed, the release of black carbon aerosols from biomass burning is the second most important factor impacting the climate system, as the increase in black carbon aerosols disturbs the atmospheric vertical wind circulation and hinders the formation of clouds, subsequently decreasing rainfall [7,8]. In addition, fires, by inducing changes in the land cover and leaf area, cause both a reduction in the canopy evaporation and transpiration, as well as an increase in the soil evaporation, as a result of the greater incidence of sunlight.

The factors controlling the occurrence and spread of fire are high temperatures, which trigger a greater degree of evapotranspiration and, in turn, reduces the moisture content of vegetation, the duration of the dry season, which determines the amount of fuel to be used, as well as the burning perimeter, the frequency of lightning, and high winds that prompt abrupt shifts in fire direction and speed [1]. On the other hand, anthropogenic related variables, such as land tenure structure, land use and management, and road network density, while significantly contributing to fire incidence, also impose, via landscape fragmentation and grazing intensity, constraints to its spreading [9]. The integrated knowledge of these factors is of fundamental importance for the development of warning systems to prevent large fires from spreading to rural and urban areas, where biomass burning pose great health risks, such as the development of ophthalmic, dermatological, heart, and lung conditions [10-17].

Between 2001 and 2002, the total estimated global burned area was 3.7 million $\mathrm{km}^{2}$ [18]. South America responded to at least $172,000 \mathrm{~km}^{2}[18,19]$, i.e., $5 \%$ of the total burned area, from which, $63 \%$ were concentrated in Brazil [20]. The concentration of fires in South America, as well as in Africa and Australia (1.4 million $\mathrm{km}^{2}$ between 2001-2002), is associated with their vast savanna ecosystems [2], characterized by long dry seasons, high temperatures, and low precipitation. In contrast, the diversity and size of plant species found in tropical forests, as well as its shorter dry period, tend to reduce fire frequency and spread [21-23].

Among the six Brazilian biomes (Cerrado, Amazon, Atlantic Forest, Pantanal, Caatinga, and the Pampas), the Cerrado, a humid savanna with an average annual rainfall ranging from 800 to $2000 \mathrm{~mm}[24,25]$, is the most adapted to fires. In fact, germination and flourishing of many endemic 
species, and soil nutrients recycling, depend on the occurrence of natural fires [26,27]. However, the continued slash-and-burn practices, through high temperature fires in order to open new areas for agriculture and pasture, also leads to the loss of nutrients, soil compaction and erosion, and loss of flora and fauna [28,29].

In this study, based on moderate resolution satellite data encompassing the 2002-2010 period, we investigated, as a preliminary and exploratory approach, the overall temporal and spatial distribution patterns of burned areas in the entire Brazilian territory, according to its major land cover types.

\section{Experimental Design}

This study, at the biome scale, and in agreement with the limits proposed by the Brazilian Institute of Geography and Statistics (IBGE) and the Ministry of the Environment (MMA), mainly relies on the map of natural vegetation coverage and land usage (PROBIO) (Conservation and Sustainable Use of Brazilian Biological Diversity Project—shapefiles and Landsat images freely available at: http://mapas.mma.gov.br/mapas/aplic/probio/datadownload.htm), based on the classification and visual interpretation of 450 Landsat-ETM scenes from 2002 [30], and on burned area data obtained from the MODIS MCD45A1 product (collection 5), which is freely available through REVERB (http://reverb.echo.nasa.gov/reverb), with a spatial resolution of $500 \mathrm{~m}$ and temporal resolution of 30 days [18,31,32]. Using the MRT tool (MODIS Reprojection Tools) [33], all the images acquired for Brazil between 2002 and 2010 were converted to GeoTIFF format, re-projected to geographic coordinates, and mosaicked.

Among the eight MCD45A1 sub-products, in our analysis, we specifically selected the Burn Date images, screened on a pixel basis according to the burned area quality assurance flags, so that only highly reliable observations were considered. Regarding the MCD45A1 validation, Boschetti et al. [34] confirmed it to be highly accurate relative to the data generated under the EFFIS (The European Forest Fires Information Service), as both products mapped a common area of 2,429 $\mathrm{km}^{2}$, which represents $83 \%$ and $89 \%$ of the total burned area, respectively (i.e., MCD45A1 2,927 $\mathrm{km}^{2}$ and EFFIS 2,722 $\mathrm{km}^{2}$ ). In another study [35], the MCD451A presented a more accurate mapping of smaller fragments of burn scars compared to the L3JRC products (Developed in collaboration between the University of Leicester, UK, Université Catholique de Louvain, Belgium, the Institute of Tropical Research, Portugal, and the Joint Research Centre of the European Commission, Italy) and GlobCarbon (Burned area product developed by the European Space Agency-ESA), due to factors such as more precise calibration and geolocation, improved atmospheric correction and cloud masking, and a higher spatial resolution.

Based on the intersection of the MCD45A1 burn scars with the limits of each biome (Amazon, Caatinga, Cerrado, Atlantic Forest, Pampa, and Pantanal), it was possible to quantify the proportion of burned area between 2002 and 2010, in relation to the respective land cover and land use classes (Figure 1).

At each biome, the PROBIO natural vegetation physiognomies were grouped into a single class, designated remnant vegetation (Figure 1). Concerning the converted areas, three classes were considered: agriculture, pasture, and others (urban perimeter, reforestation, mining areas, and water)(Arc of deforestation limits provided by the Brazilian Environmental Agency (IBAMA)). 
Figure 1. Spatial distribution of the total burned area (2002-2010) within the six Brazilian biomes, relative to the major land cover and land use classes (PROBIO) (Arc of deforestation limits provided by the Brazilian Environmental Agency (IBAMA)).

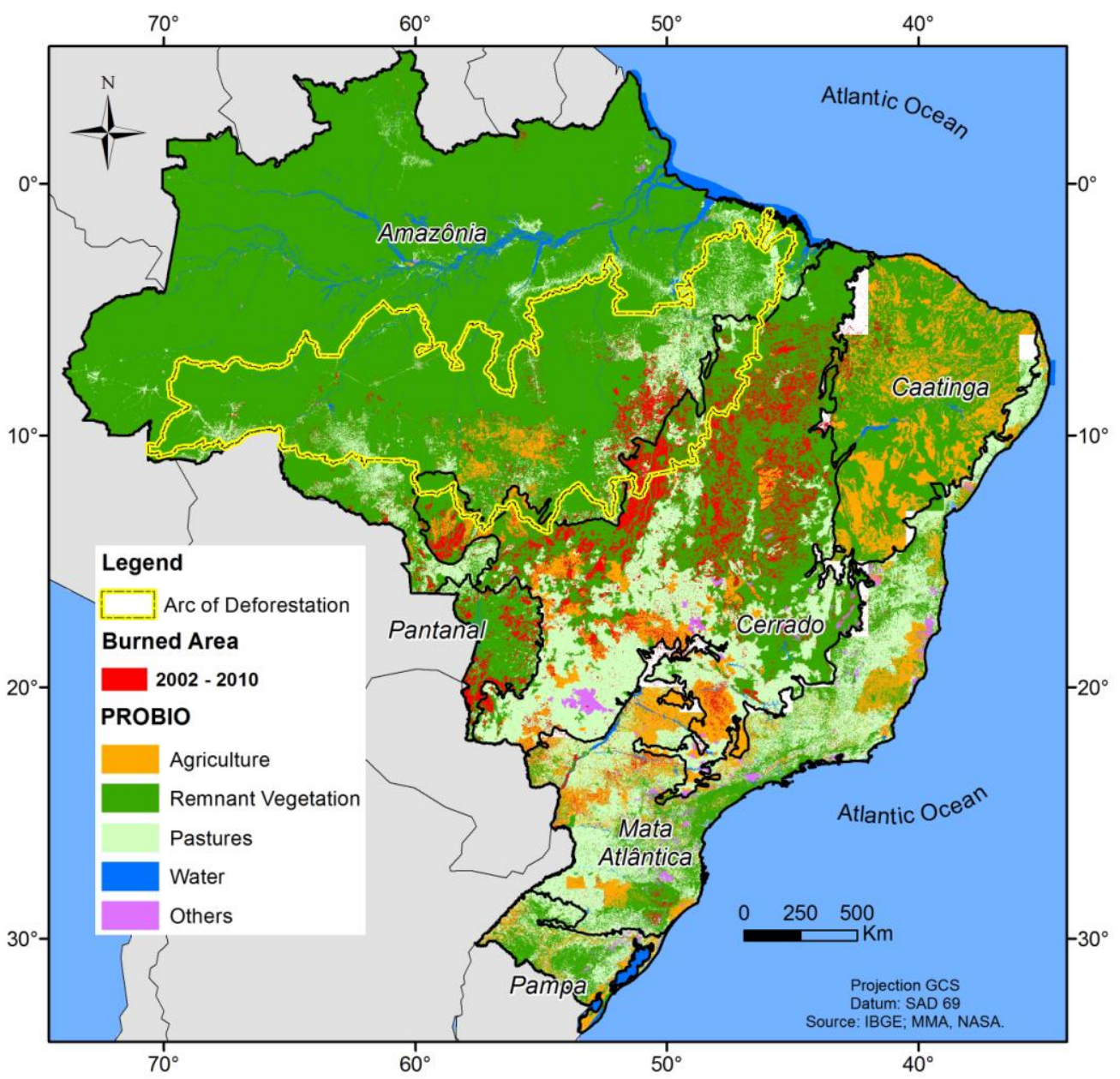

For comparative purposes, concurrently with the MCD45A1 data analysis, we also evaluated, relative to the biome limits and for the 2002-2010 period, the (collection 5) MOD14 and MYD14 fire hotspots, based on the Terra (10:30 and 22:30 overpasses) and Aqua (13:30 and 01:30 overpasses) MODIS data (Data available for download through the CPTEC-INPE (Center of Weather Forecast and Climatic Studies): http://www.dpi.inpe.br/proarco/bdqueimadas/). The daily active fire product (i.e., MOD14 and MYD14 hotspots), at $1 \mathrm{~km}$ spatial resolution, is based on the brightness temperatures derived from bands 21 (centered at $3.9 \mu \mathrm{m}$ ) and 22 (centered at $11 \mu \mathrm{m}$ ), which saturate at approximately $500 \mathrm{~K}$ and $331 \mathrm{~K}$, respectively [36]. False fire detections are screened with the use of the optical red (centered at $0.65 \mu \mathrm{m}$ ) and near infrared (centered at $0.86 \mu \mathrm{m}$ ) MODIS bands, resampled to $1 \mathrm{~km}[31,36]$.

As the amount of precipitation during the year, which determines the humidity deficit of the fuel material, especially during the dry season, plays a key role in understanding the intensity and extension of burned areas, TRMM (Tropical Rainfall Measurement Mission) monthly precipitation, with spatial resolution of $25 \mathrm{~km}\left(0.25^{\circ}\right)$, was also included in the analysis [37,38].

Precipitation anomaly curves, according to the Armenteras-Pascual et al. [39] parameters, were derived as follow: 


$$
\text { PPT anomaly in year }{ }_{i}=\frac{\text { mean PPT in year }{ }_{i} \text {-mean PPT (2002 to 2010) }}{\text { mean standard deviation }(2002 \text { to } 2010)}
$$

where positive anomaly values indicate years with above average rainfall for the period, while negative anomaly values indicate years with rainfall below the average for the period.

All the methodological procedures involved in this study, including data acquisition, processing, sampling, and analysis are detailed in the flowchart shown in Figure 2.

Figure 2. Schematic flowchart depicting the main steps and approaches followed in this study.

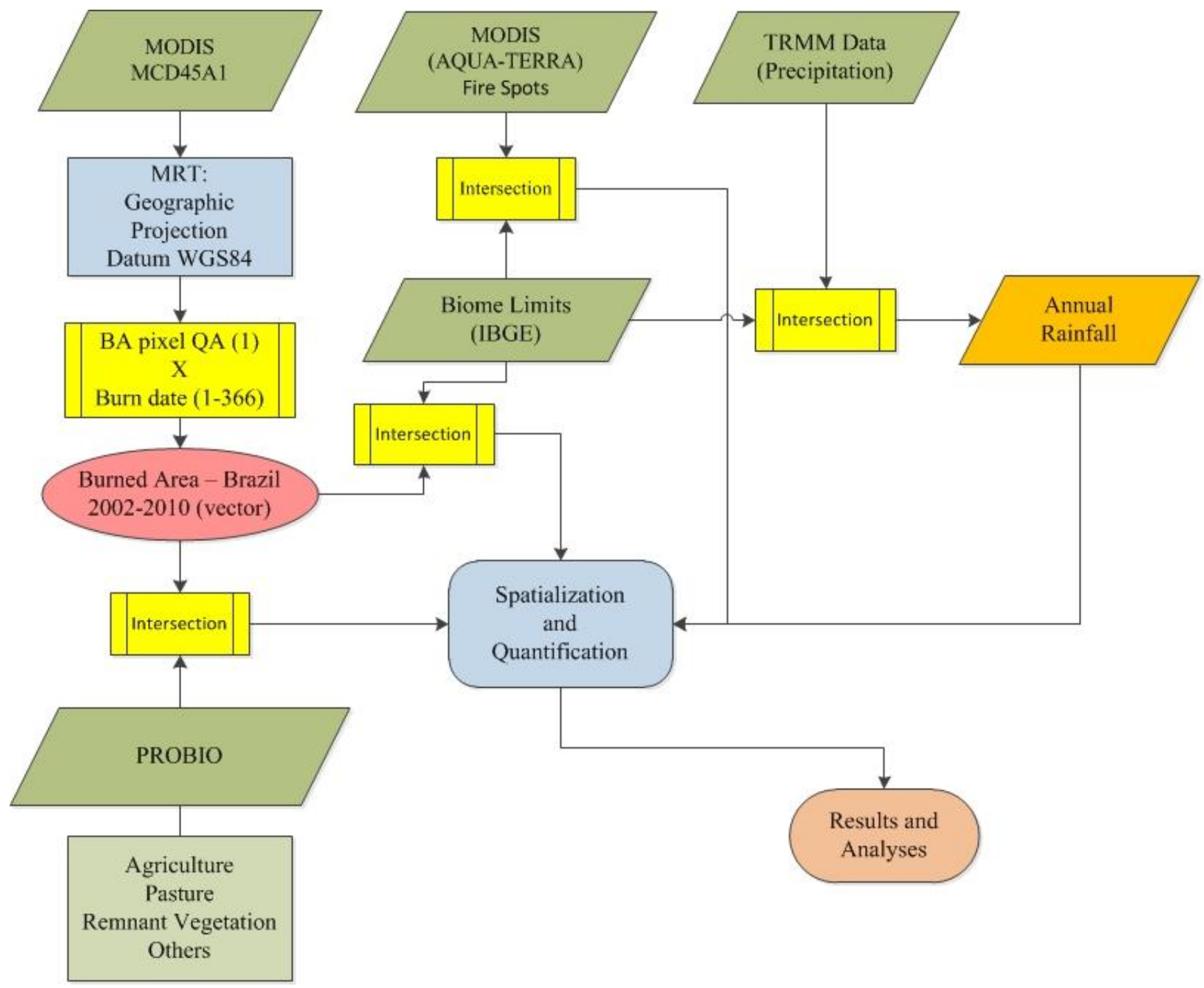

\section{Results and Discussion}

The total burned area, by period and for each biome, is shown in Table 1 and Figure 3. For all the years considered, it is interesting to observe the concentration of burned areas in the Cerrado biome, was nearly 73\%, followed by the Amazon biome (14\%), and Pantanal (6\%). In relation to the Pampa and Altantic Forest biomes, the incidence of fires is significantly less, considering the greater precipitation regime throughout the year and the predominance of wet grasslands and arboreal canopies. 
Table 1. Annual extension of the total burned area (in $1,000 \mathrm{~km}^{2}$ ) in the Brazilian territory (biomes) for the 2002-2010 period.

\begin{tabular}{lcccccccccc}
\hline Biomes & $\mathbf{2 0 0 2}$ & $\mathbf{2 0 0 3}$ & $\mathbf{2 0 0 4}$ & $\mathbf{2 0 0 5}$ & $\mathbf{2 0 0 6}$ & $\mathbf{2 0 0 7}$ & $\mathbf{2 0 0 8}$ & $\mathbf{2 0 0 9}$ & $\mathbf{2 0 1 0}$ & Total \\
\hline Amazon & 10 & 8 & 11 & 13 & 6 & 25 & 6 & 2 & 27 & 108 \\
Caatinga & 1 & 1 & 1 & 2 & 0.6 & 5 & 1 & 0.4 & 4 & 17 \\
Cerrado & 60 & 32 & 47 & 47 & 28 & 129 & 46 & 11 & 147 & 545 \\
Atlantic Forest & 3 & 5 & 3 & 2 & 2 & 4 & 2 & 1 & 5 & 27 \\
Pampa & 0.3 & 0.7 & 0.4 & 0.2 & 0.2 & 0.5 & 0.2 & 0.3 & 0.4 & 3 \\
Pantanal & 8 & 1 & 6 & 14 & 1 & 8 & 2 & 2 & 6 & 48 \\
Total & 82 & 48 & 69 & 78 & 38 & 170 & 57 & 17 & 189 & 748 \\
\hline
\end{tabular}

Figure 3. Distribution of the burned areas in the Brazilian biomes, between 2002 and 2010.

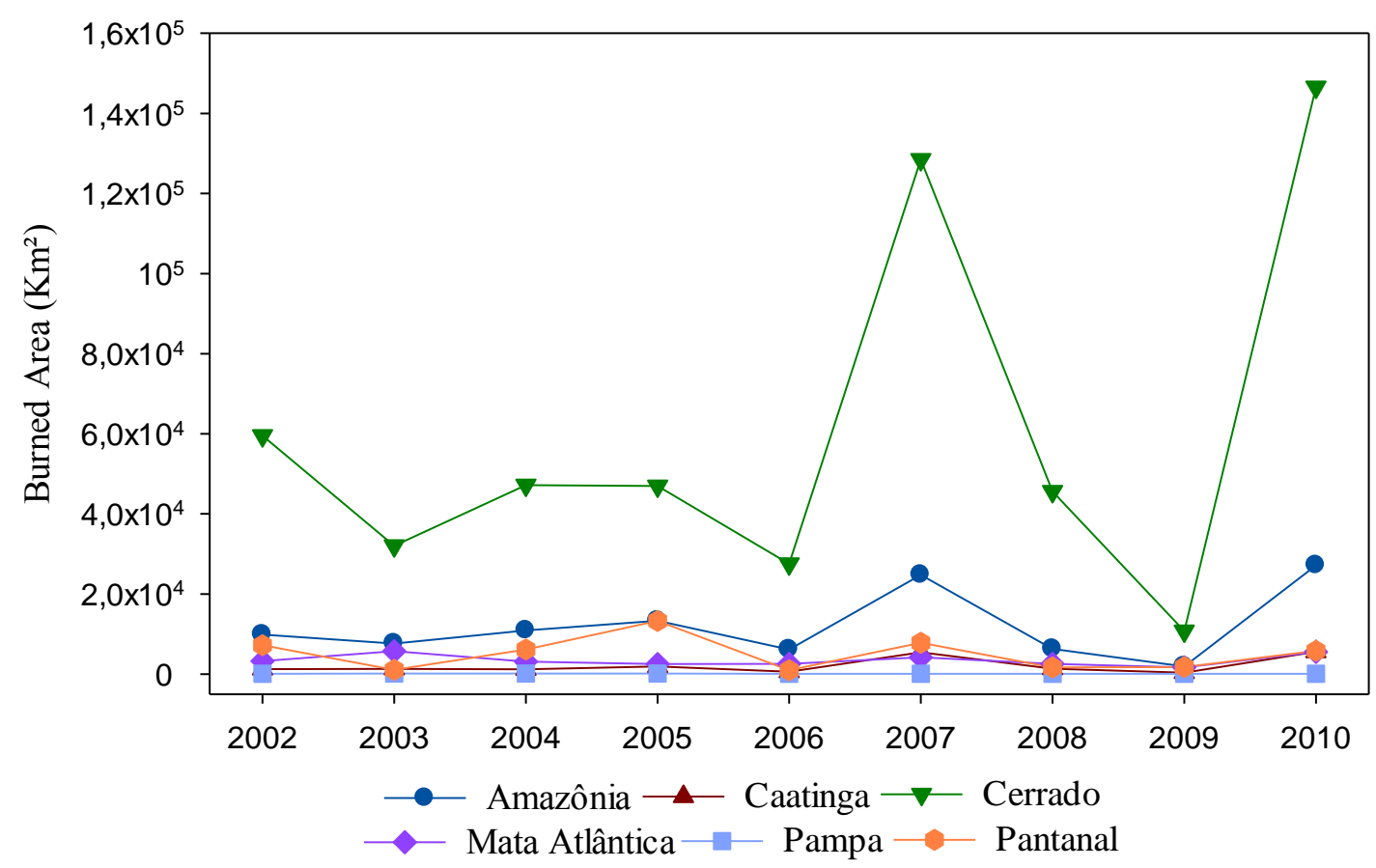

Similarly, in the Caatinga, burnings are less pronounced $(\sim 3 \%)$, considering the rather irregular extensive dry period, and the litter material being less susceptible to complete combustion in fires of less intensity $[23,40]$.

It is worth noting (Table 1 and Figure 3) the increase in burned area, particularly in the Cerrado and Amazon, in the years of 2007 and 2010. In fact, in these two years, characterized by strong La Niña events [41], these biomes concentrated $90 \%$ and $92 \%$ of the total burned area in Brazil, respectively, as well as $87 \%$ of the total burned area in Brazil during the whole period considered in our analysis. Another relevant point that draws attention in Table 1 is the comparatively much lower figures, across biomes, in 2009, which demands further investigation concerning both sensor overall performance and specific MCD45A1 related issues, as well as local circumstances and peculiarities.

Although the Cerrado biome, between 2002 and 2010, presented, at every year, the largest burned area (Figure 3), the Amazon showed the highest record of hotspots in its domain, followed by the Cerrado (Figure 4). Interestingly, while in the Cerrado the distribution pattern of these hotspots tends to closely follow that observed for the burned areas, in the Amazon, the amount of hotspots and burned 
areas describe opposite trends (Figures 3 and 4), i.e., in 2009, the year with the smallest burned area $\left(1,931 \mathrm{~km}^{2}\right)$, the recorded hotspots were $30 \%$ larger than those observed in 2010 , the year with the largest burned area $\left(27,251 \mathrm{~km}^{2}\right)$.

Figure 4. Distribution of thermal anomalies (fire hotspots) in the Brazilian biomes, between 2002 and 2010.

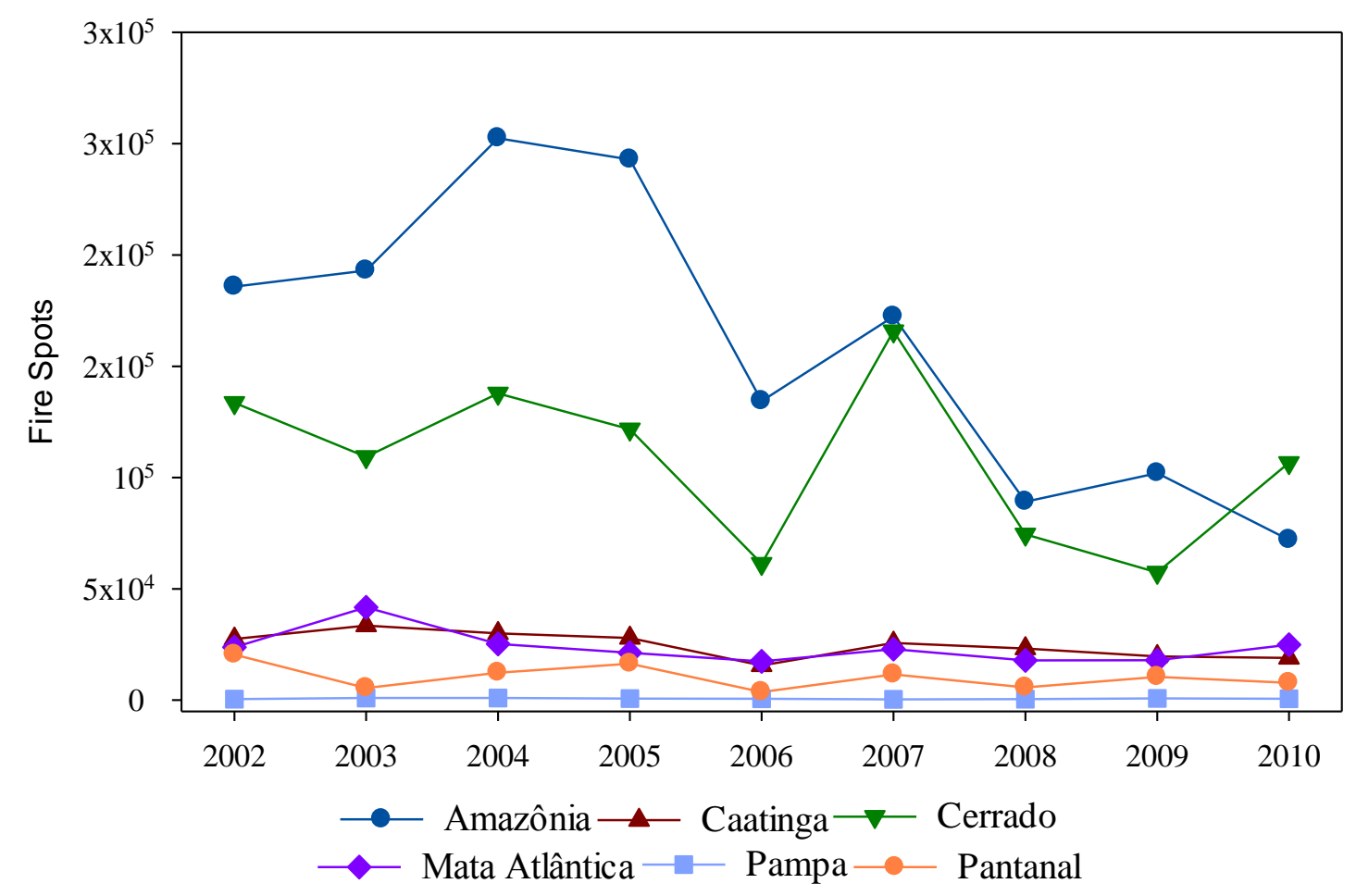

In part, these differences in behavior reflect a lower accuracy of the MCD45A1 in dense vegetation areas, like in the Amazon region [42], where omission errors are more likely to occur due to the interference of clouds and plumes (optical depth), accidental fires with low chance of propagation, obscuration of fires by the overstory vegetation, and the average size of burns, usually smaller than the spatial resolution of the sensor $(500 \mathrm{~m})$ [18]. Likewise, the MOD14, though very effective in the discrimination of fires with different intensities, is also subject to omission errors, as in the case of fires not coincident with the satellite overpass or too small to be detectable, and limited regarding area determination $[43,44]$. Nevertheless, in the Arc of Deforestation, marked by severe fire activity, thermal anomalies detections are twofold higher than anywhere in the world [43]. This accentuated fire intensity, along the Amazon-Cerrado transition, is clearly seen in both the MCD45A1 and MOD14/MYD14 products (Figure 5).

According to the World Meteorological Organization (WMO) data, the 2001-2010 decade was the hottest, globally, since 1850 (beginning of the temperature records), and the year 2010, with temperatures much above the average in the north region of South America, was the second hottest year since 1998. Likewise, for the years of 2007 and 2010, the effects of La Niña were stronger than those presented by El Niño, mainly in August [41]. Data from CPTEC-INPE also shows that the 2004-2005 and 2006-2007 periods had the weakest El Niño events, not significantly contributing to the occurrence of severe droughts, which are one of the drivers of fire. Nevertheless, August 2007 marked the beginning of a strong La Niña event, during the 2007-2008 period (Figure 6). 
Figure 5. (A) Total burned area (MCD45A1); and (B) fire hotspots (MOD14 and MYD14), between 2002 and 2010, according to the Brazilian municipalities.
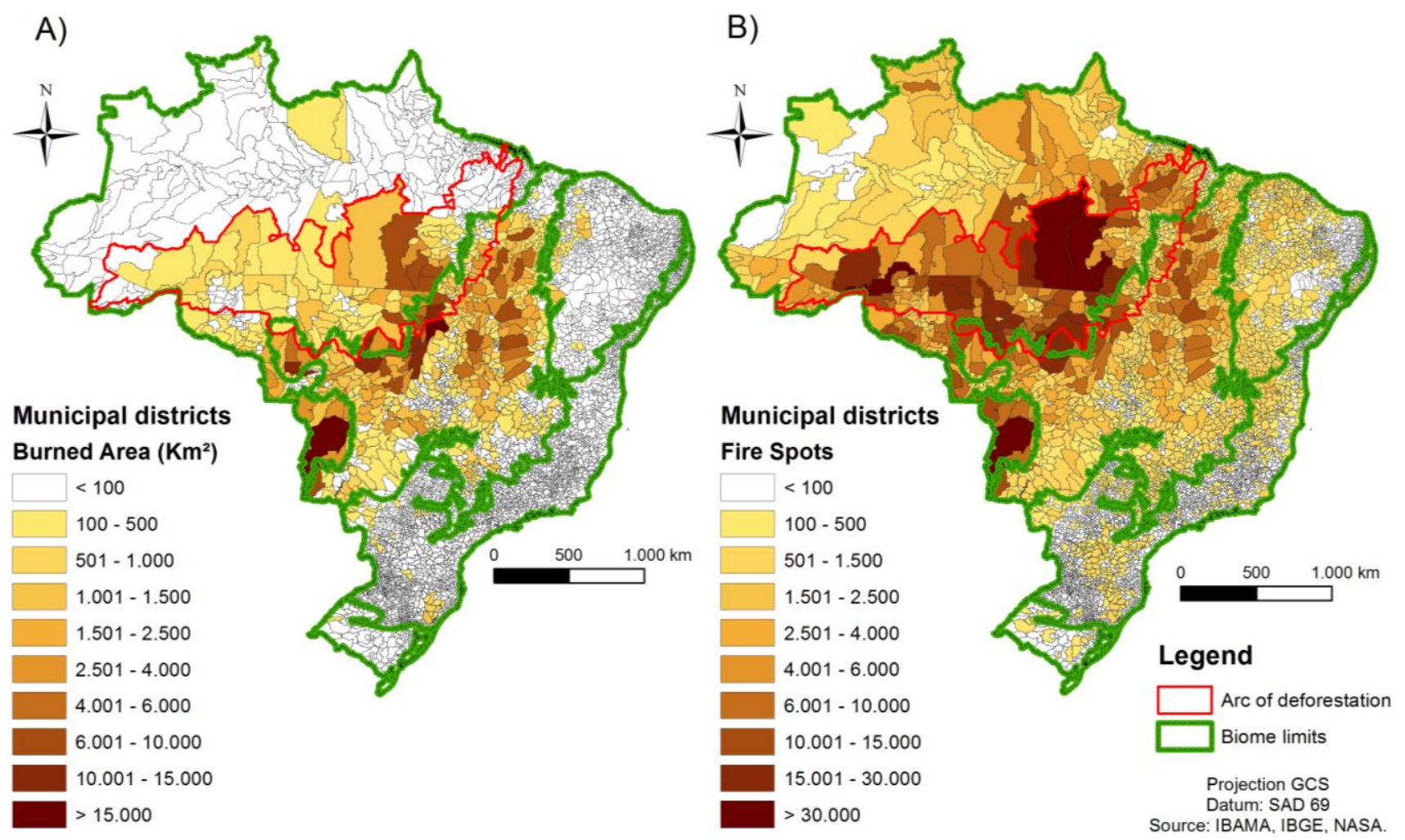

Figure 6. Distribution of El Niño and La Niña events between 2002 and 2010 (ENSO = El Niño Southern Oscillation). Source: NOAA [45]

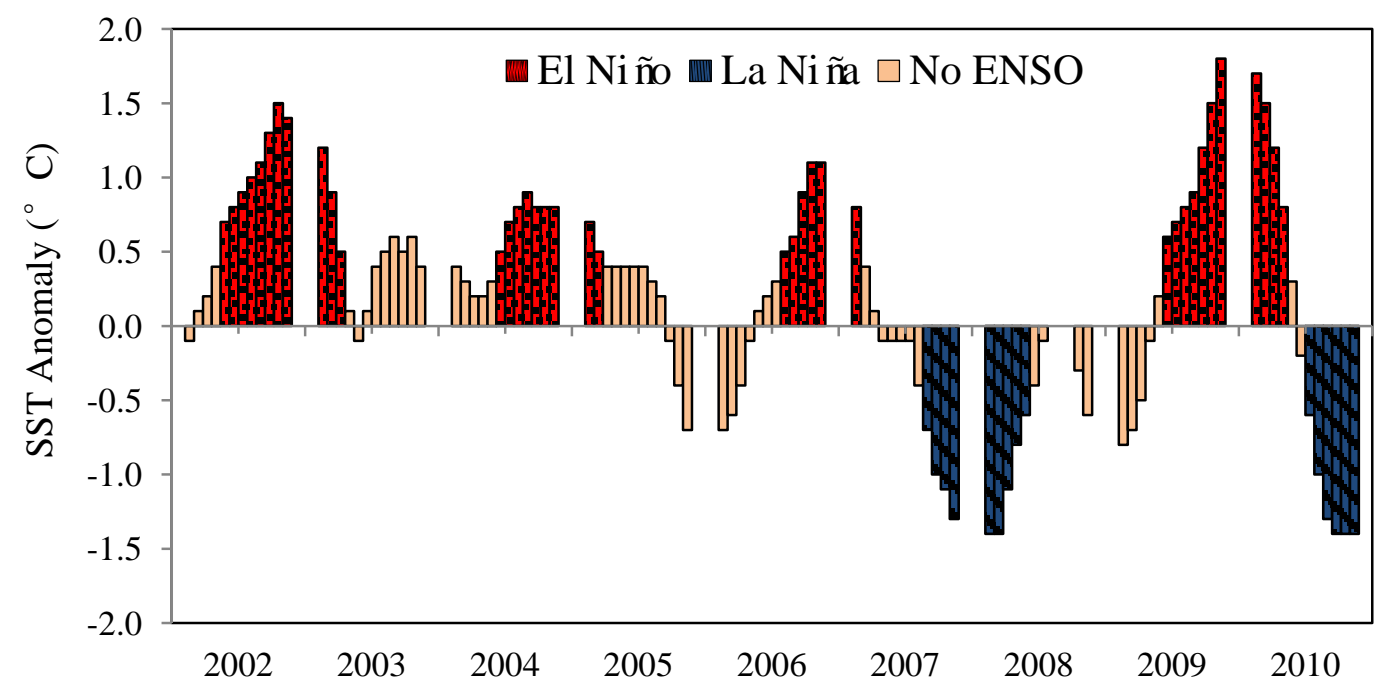

In relation to the precipitation for the 2003, 2007, and 2010 years, the Amazon, Cerrado, Caatinga, and Atlantic Forest biomes presented a lower annual mean relative to both the previous year and to the total period. For the Cerrado, the year of 2007 was, on average, $32 \mathrm{~mm}$ drier than 2006, and had the strongest negative anomaly $(-1.13 \mathrm{~mm}$ ) (Figure 7$)$, while 2010 showed a mean annual precipitation $29 \mathrm{~mm}$ less than 2009 , and had the second strongest negative anomaly $(-0.51 \mathrm{~mm})$. In this same year, the Amazon had a negative anomaly of $-0.41 \mathrm{~mm}$. 
Figure 7. Annual mean precipitation anomalies (2002 to 2010) in the Brazilian biomes.

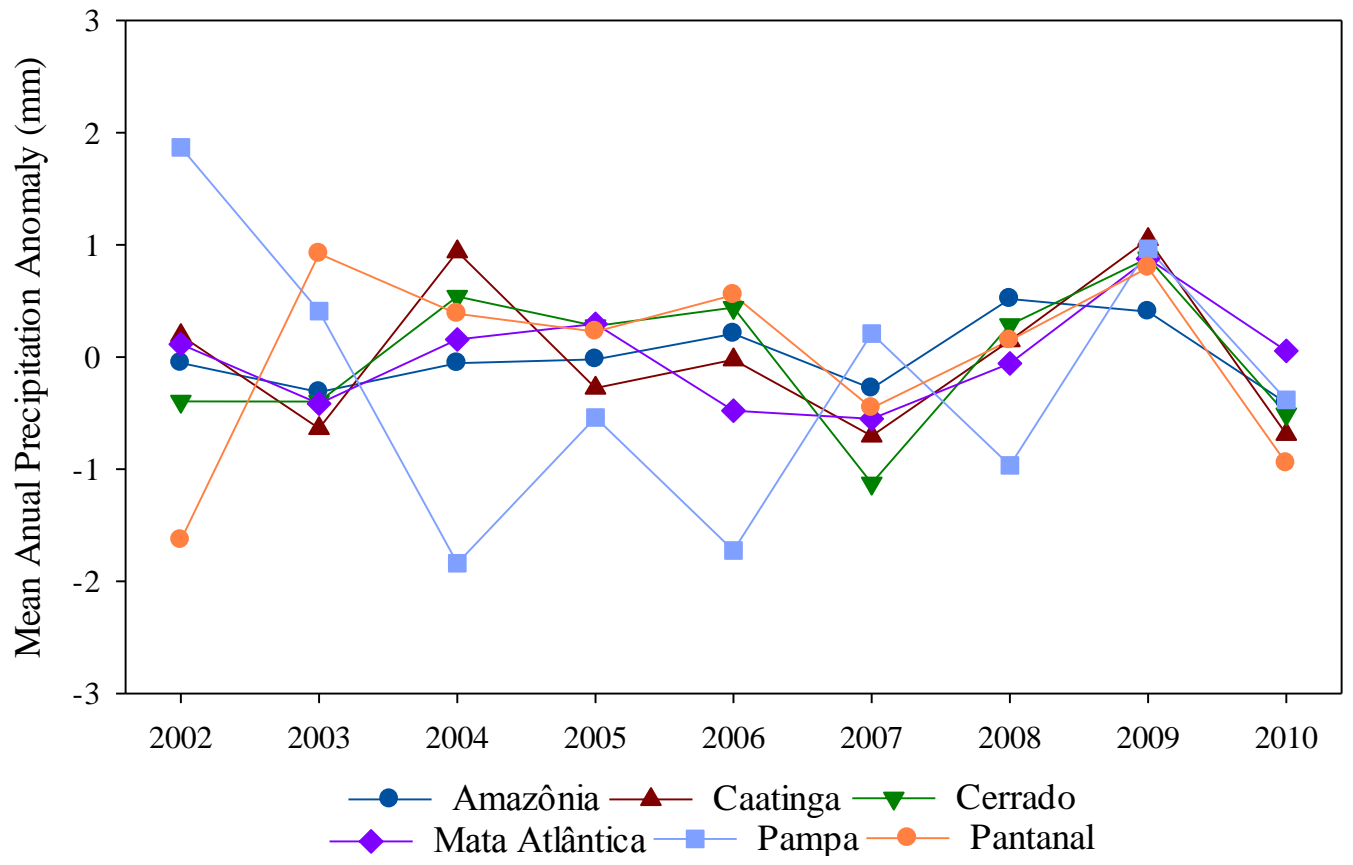

According to [46], negative anomalies of monthly precipitation during a La Niña event are observed mostly in the Southeastern, Central-Western, and in the Northeastern (Southern portion) regions of the country, particularly in the months of January and February. Though the effects of the El Niño and La Niña phenomenon tend to be less pronounced in the Cerrado biome, the precipitation increase in the months of January and February 2010, related to an El Niño, followed by a La Nina event started in March, caused both a substantial increment in biomass, as well as a prolonged and more intensive than usual dry season. These conditions, favoring abundant fuel and propagation, induced burns of great proportions in 2010.

Regarding the concentration of burned areas in the year 2005 in the Amazon biome, this was the result of high SST (sea surface temperatures) in the North Atlantic, in both 2005 and 2010, which reduced the moist air masses in the Amazon [47-49]. As a matter of fact, the drought of 2010 in the Amazon was spatially more extensive, and more severe, than in 2005, with two epicenters, one in the southwestern region of the Amazon, and the other in the state of Mato Grosso, in its Central-Western portion [49].

Fires in the Brazilian territory show a period of greater intensification, particularly in the Cerrado, during the months of July, August, and September. The period between May and September in the Cerrado records the lowest values of relative air humidity due to a drastic drop in rainfall, elevation of the relative air temperature, and the increase in the amount of incident solar radiation throughout the day. These favorable environmental conditions, in conjunction with a larger amount of thin combustible material (grasses and leaves, alive or dead, and thin branches, with diameter around $6 \mathrm{~mm}$ ) available in the environment, both from the herbaceous layer and from exotic species (e.g., Brachiaria Decumbens), promotes the occurrence of fires (Figure 8) [50]. 
Figure 8. Distribution of monthly mean precipitation (2002 to 2010) in the Brazilian biomes (TRMM data).

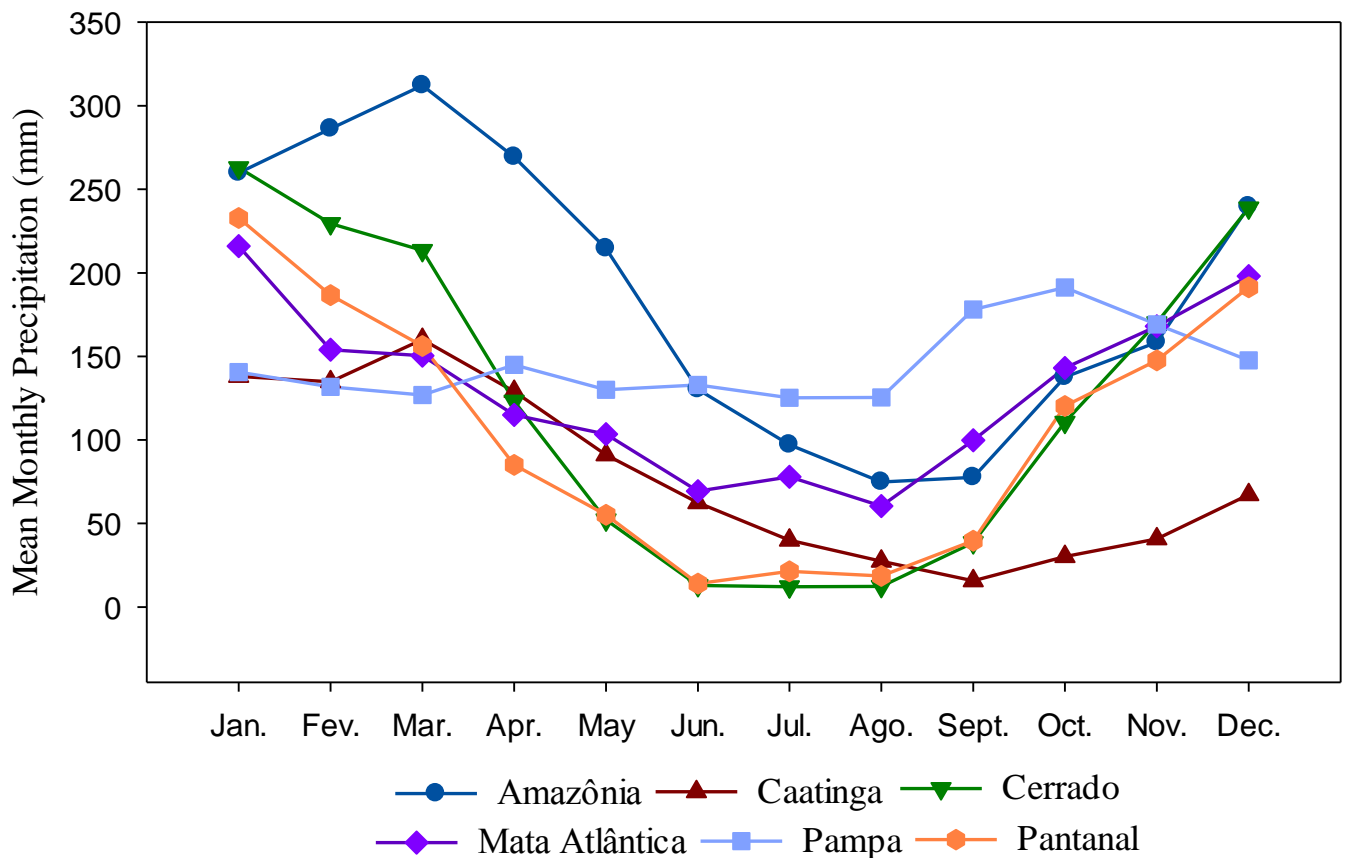

As depicted in Figure 8, a clear similarity in the distribution of mean monthly precipitation (mm) throughout the year is observed between the Cerrado and Pantanal biomes, with the largest occurrences of precipitation concentrated in the November to March period, due to the increased activity of the Continental Equatorial (cE) air mass, which is composed of moist air masses with high temperatures that cause abundant rainfall in the summer. However, in the winter, the $\mathrm{cE}$ air mass retreats to the northern region of the Amazon, along with the Intertropical Convergence Zone (ITCZ), resulting in the drop of both temperature and moisture content [51,52].

\subsection{Burned Areas \& Land Cover Classes}

As suggested in Figure 9, during the nine years investigated, and according to the PROBIO data, the remnant vegetation cover was the most affected by burns ( $81 \%)$, while only $19 \%$ of the burned areas were directly associated with land already in use, especially in the Cerrado and Amazon regions, with the purpose of agriculture management, reclaiming of abandoned land, or the consolidation of occupation frontiers [16,53-60].

Although no unequivocal relationship can be established between burned areas and new land conversions, the conspicuous concentration of burns in the Arc of Deforestation and in the Cerrado northeastern portion should not be taken as a simple coincidence (Figures 1 and 5). In these two most prominent agricultural frontiers, in addition to recurrent and naturally occurring fires, human induced burning, strengthened by peculiar climatic circumstances, certainly plays a major role and accounts, directly or indirectly, for most of the fire-affected area. 
Figure 9. Distribution and proportion of burned areas in the Brazilian territory, between 2002 and 2010, according to the remnant vegetation and major land use classes.

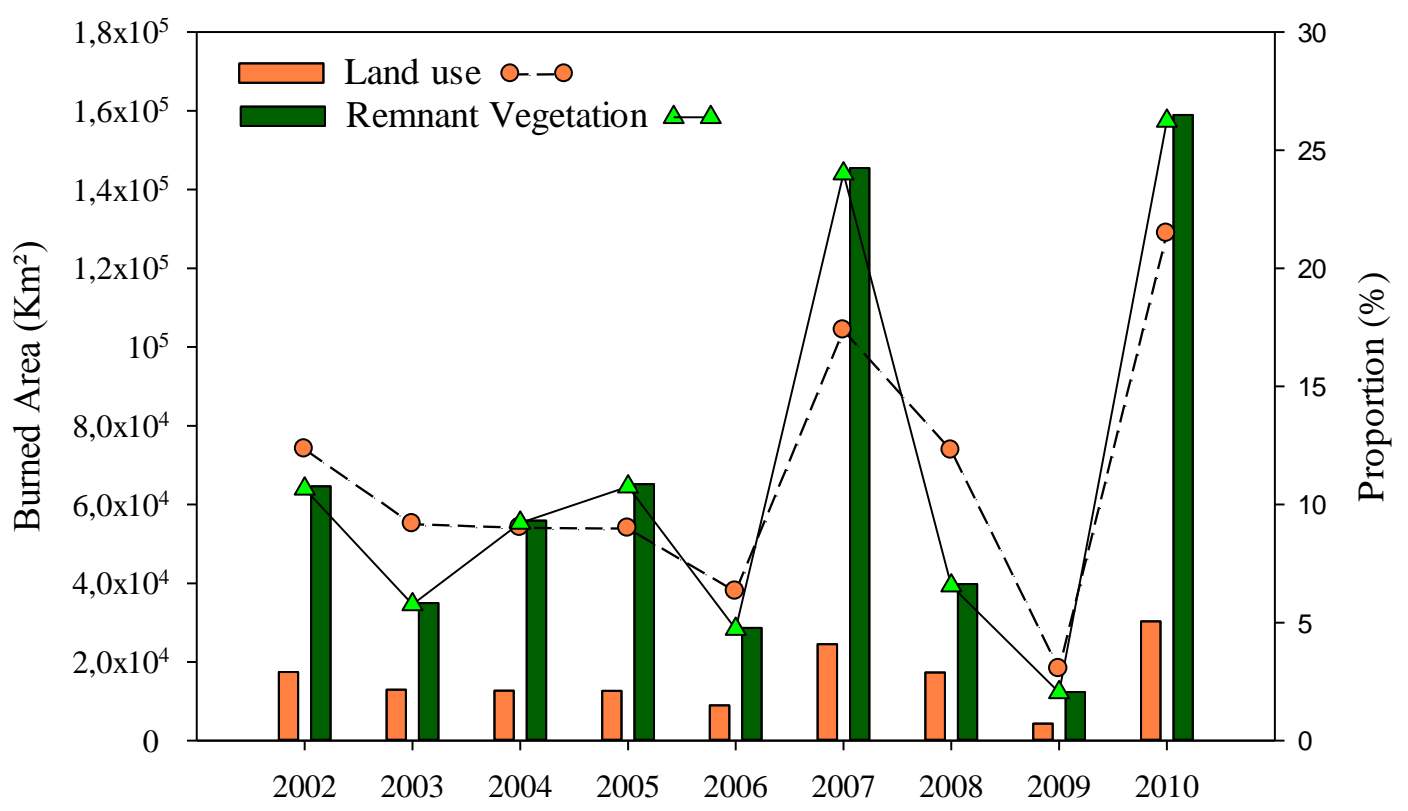

Specifically, approximately $80 \%$ of the total annual burned area in the Cerrado, Caatinga, and Pantanal occurs in landscapes dominated by remnant vegetation. In the case of the Caatinga (Figure 10(B)), the low incidence of fires in anthropic areas is mainly due to the intermittent and scattered character of its cattle ranching activity. In the Pantanal (Figure 10(D)), though cattle ranching is prominent, the dominance of moist and green grasslands, coupled with management practices less dependent on fire, help to explain the concentration of burns over remnant vegetation areas, especially among the savanna physiognomies undergoing conversion.

In the Cerrado, the main agricultural frontier of the country, the prevalence of fires over remnant vegetation is associated with the still very active and significant clearings [61-64], although the intensity and spreading of fires, over both natural and converted areas, are also dependent on the severity of the climatic events, as previously discussed. In fact, the occurrence of fires in the Cerrado is highly seasonal. During October to April (wet season), there is a substantial increase in the amount of biomass, while in the dry season (May to September), the biomass becomes highly flammable and susceptible to a rapid spread of fire over great extensions of natural vegetation. Nevertheless, it is important to emphasize that 2010, the year with the largest detection of fire scars in the Cerrado, had $19,121 \mathrm{~km}^{2}$ of burned areas over pastures and 11,315 $\mathrm{km}^{2}$ over agriculture, corresponding to $10 \%$ and $6 \%$ of the total burned areas in the country in that year, respectively (Figure 10(F)).

Significant areas of pastures $(>20 \%)$ are also annually burned in the Amazon, Pampa, and Atlantic Forest (Figure 10). In the Pampa (Figure 10(A)), which is characterized by extensive grazing over natural and cultivated pastures, from 2005 on, the total burned area over both pastures and remnant vegetation tended to become closer, with the exception of 2010, which had the largest burned area over pastures $(45.6 \%)$. 
Figure 10. Distribution of burned areas (\%), according to the major land cover classes, in the six Brazilian biomes (2002 to 2010): (A) Pampa; (B) Caatinga; (C) Atlantic Forest; (D) Pantanal; (E) Amazon, and (F) Cerrado.

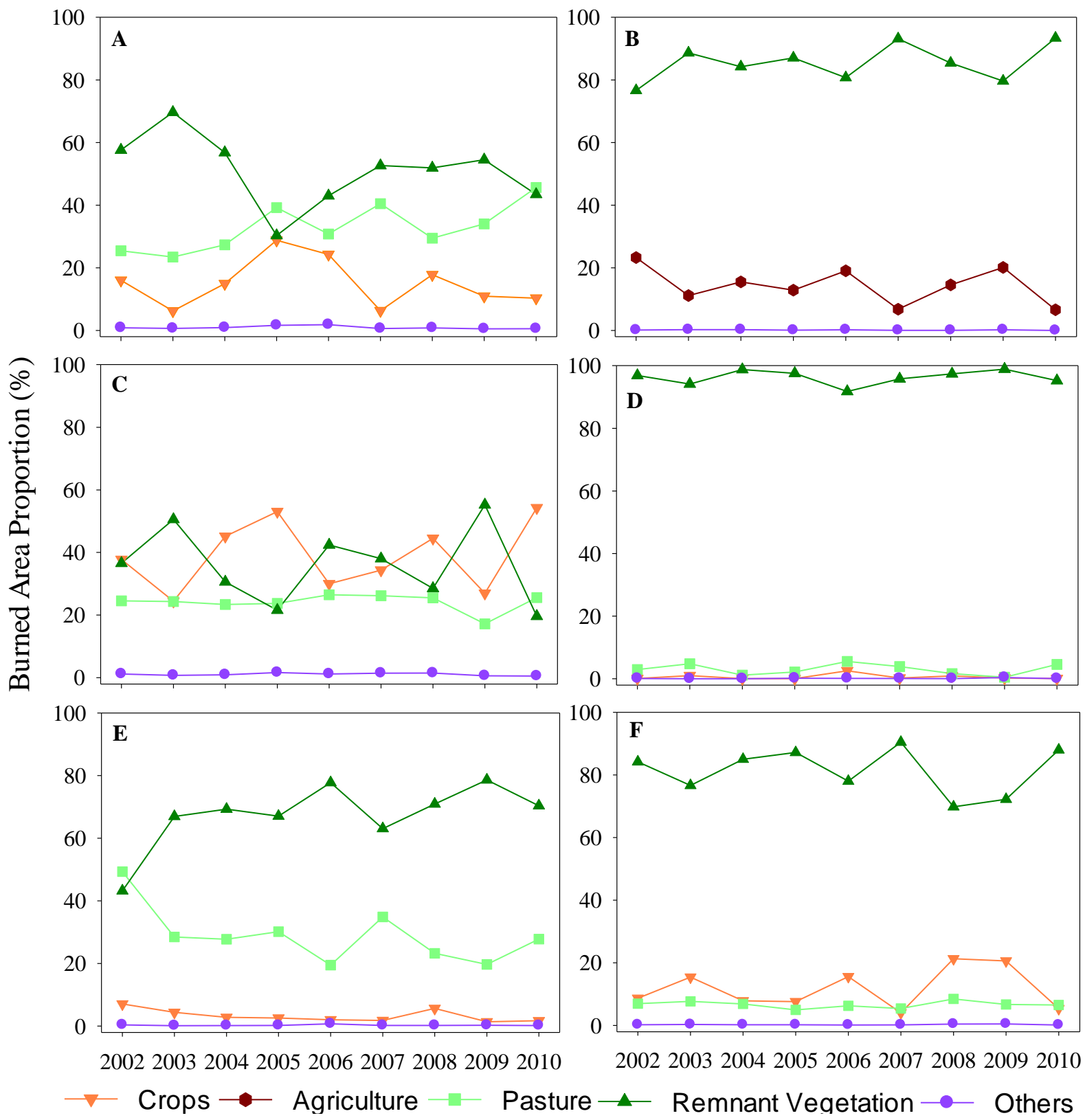

In the Amazon (Figure 10(E)), a large amount of fires serves the purpose of recovering old pastures taken by invading species and secondary growth $[56,57,65,66]$. Indeed, pasture management in Amazon is the main cause behind the spread of fire to primary and secondary forests, particularly near areas already converted for human activities, where reduced and discontinued vegetation canopy allow for more sunlight to reach the forest floor, consequently increasing the amount of dry biomass and the forest flammability [67]. In Figure 10e it is also interesting to note the symmetric and complementary pattern of burned areas over pasture and remnant vegetation, suggesting that years of intensive pasture use correspond to lower pressure over the natural vegetation. Such trends and patterns take place mostly at the transition zone with the Cerrado biome (i.e., the Arc of Deforestation), characterized by intense anthropic occupation [48,68-73]. 
In relation to the Atlantic Forest (Figure 9(c)), it is noteworthy the well distributed occurrence of burned areas over the remnant vegetation $\left(35 \%\right.$ or $\left.9,617 \mathrm{~km}^{2}\right)$, pastures $\left(25 \%\right.$ or $\left.6,651 \mathrm{~km}^{2}\right)$, and agricultural fields $\left(39 \%\right.$ or $\left.10,553 \mathrm{~km}^{2}\right)$, as the sugarcane plantations, mostly found in this biome, still use fire to assist in the harvest [17,74-76]. It should be emphasized, however, that these numbers do not reflect the real magnitude of the agricultural area subject to fires in the Atlantic Forest domains, as the spatial resolution of the MCD45A1 product is often too coarse to capture the mean patch size and fragmentation of the cultivated fields, and large omission errors are also likely to occur due to the prevalent cloudy conditions in April, when most of the harvest begins. Indeed, only in the State of São Paulo, around $20,000 \mathrm{~km}^{2}$ of sugarcane plantations are submitted to the straw burning practice every harvesting season [77,78]. Based on an agreement between the government of São Paulo and the Sugarcane Industry (UNICA), supported by the state legislation $\mathrm{N}^{\circ} 11.241 / 2002$, the expectation is that, as of 2017, all sugarcane harvesting will be mechanized, which should significantly contribute to reduce fires in the Atlantic Forest [76].

\section{Concluding Remarks}

In this study, based on the use of the MODIS MCD45A1 product, we investigated the spatial and temporal distribution patterns of burned areas in Brazil, according to its six main ecological regions. Overall, between 2002 and 2010, approximately 73\% of the burned areas occurred in the Cerrado biome, followed by $15 \%$ in the Amazon region, $6 \%$ in the Pantanal, $4 \%$ in the Altantic Forest, $0.4 \%$ in the Pampa, and $2 \%$ in the Caatinga. Concerning the thermal anomalies (hotspots), $49 \%$ and $33 \%$ of them, for the total period considered, were detected in the Amazon and Cerrado, respectively. Despite the observed discrepancies between the MOD14/MYD14 and MCD45A1, regarding the relative concentration of fire scars and hotspots, both products were able to clearly depict the severe fire activity along the Amazon-Cerrado transition, an area of intensive land-use and land-cover change known as Arc of Deforestation.

Regarding the main land cover types (based on the 2002 PROBIO map), with the exception of the Atlantic Forest, which is, proportionally, the most converted biome in Brazil, fire scars, for the period investigated, occurred predominately over remnant vegetation $(81 \%)$ and, to a less extent, over pastures $(11 \%)$. Although caution is definitely required when attempting to interpret these figures, due to both data constraints and to the fact that no unequivocal correlation can be established between burned areas and new land conversions, they do suggest that fire, regardless of its serious environmental impact, is still an important instrument for the occupation of new areas, as well as for the management and clearing of pastures.

The evaluation, in a systematic and preventive manner, of the vulnerability of the distinct landscapes to the occurrence of fires is a critical issue in Brazil. To this end, the combined use of different remote sensing products is instrumental. While different studies show the ability of the MCD45A1 product for detecting burned areas at landscape scale, the use of other satellite data, such as precipitation (e.g., TRMM) and evapotranspiration (e.g., MOD16), associated with vegetation indices (e.g., MOD13), certainly can contribute in modeling susceptible areas based on biomass availability under favorable climatic conditions. 


\section{Acknowledgments}

This study was conducted with support from the Brazilian Research Council (CNPq/grant number 471198/2009-9), the NASA Terrestrial Ecology Program (grant number NNX08AI24G), and the NASA Land-Cover/Land-Use Change Program (grant number NNX11AE56G). Fernando Moreira de Araújo and Laerte Guimarães Ferreira also acknowledge CNPq for individual research grants. We are also grateful to the three anonymous reviewers for their useful comments and suggestions on the manuscript.

\section{References}

1. Jin, H. Drivers of Global Wildfires-Statistical Analyses. Ph.D. Dissertation, University of Lund, Lund, Sweden, 2010.

2. Bond, W.J.; Woodward, F.I.; Midgley, G.F. The global distribution of ecosystems in a world without fire. New Phytol. 2005, 165, 525-538.

3. Van der Werf, G.R.; Randerson, J.T.; Giglio, L.; Collatz, G.J.; Kasibhatla, P.S.; Arellano, A.F.; olsen, S.C. Kasischke, E.S. Continental-scale partitioning of fire emissions during the 1997 to 2001 El Niño/La Niña period. Science 2004, 303, 73-75.

4. Bowman, D.M.J.S.; Balch, J.K.; Artaxo, P.; Bond, W.J.; Carlson, J.M.; Cochrane, M.A.; D'Antonio, C.M.; DeFries, R.S.; Doyle, J.C.; Harrison, S.P.; et al. Fire in the earth system. Science 2009, 324, 481-484.

5. Field, C.B.; Jackson, R.B.; Mooney, H.A. Stomatal responses to increased $\mathrm{CO}_{2}$ : Implications from the plant to the global scale. Plant Cell Environ. 1995, 18, 1214-1225.

6. Roderick, M.L.; Farquhar, G.D. The cause of decreased pan evaporation over the past 50 years. Science 2002, 298, 1410-1411.

7. Ramanathan, V.; Carmichael, G. Global and regional climate changes due to black carbon. Nat. Geosci. 2008, 1, 221-227.

8. Freitas, S.R.; Longo, K.M.; Silva Dias, M.A.F.; Silva Dias, P.L. Emissões de queimadas em ecossistemas da América do Sul. Estud. Avançad. 2005, 19, 167-186.

9. Archibald, S.; Roy, D.P.; van Wilgen, B.W.; Scholes, R.J. What limits fire? An examination of drivers of burnt area in Southern Africa. Glob. Change Biol. 2009, 15, 613-630.

10. Mims, F.M., 3rd. Health effects of tropical smoke. Nature 1997, 390, 222-223.

11. Kunii, O. Health Guidelines for Vegetation Fire Events: Background Papers; Goh, K., Schwela, D., Goldammer, J.G., Simpson, O., Eds.; World Heath Organ: Geneva, Switzerland, 1999.

12. Ribeiro, H.; Assunção, J.V. Efeitos das queimadas na saúde humana. Estud. Avançad. 2002, 16, 125-148.

13. Cançado, J.E.D. A poluição Atmosférica e sua Relação com a Saúde Humana na Região Canavieira de Piracicaba-SP. Ph.D. Dissertation, Faculdade de Medicinada/USP, São Paulo, Brazil, 2003.

14. Arbex, M.A.; Cançado, J.E.D.; Pereira, L.A.A.; Braga, A.L.; Saldiva, P.H.N.; Queima de biomassa e efeitos sobre a saúde. J. Bras. Pneumol. 2004, 30, 158-175. 
15. Mascarenhas, M.D..; Vieira, L.C.; Lanzieri, T.M.; Leal, A.p.; Duarte, A.F.; Hacth, D.L. Anthropogenic air pollution and respiratory disease-related emergency room visits in Rio Branco, Brazil-September, 2005. J. Bras. Pneumol. 2008, 34, 42-46.

16. Mendonça, M.J.C.; Vera Diaz, M.D.C.; Daniel, D.C.; Seroa, R.; Alencar, A.; Gomes, J.C.; Ortiz. R.A. The economic cost of the use of fire in the Brazilian Amazon. Ecol. Econ. 2004, 49, 89-105.

17. Ribeiro, H. Queimadas de cana-de-açúcar no Brasil: Efeitos à saúde respiratória. Rev. Saúde Pub. 2008, 42, 370-376.

18. Roy, D.P.; Boschetti, L.; Justice, C.O.; Ju, J. The collection 5 MODIS burned area product-Global evaluation by comparison with the MODIS active fire product. Remote Sens. Environ. 2008, 112, 3690-3707.

19. Chang, D.; Song, Y. Comparison of L3HRC and MODIS global burned area products from 2000 to 2007. J. Geoph. Res. 2009, 114, doi:10.1029/2008JD011361.

20. Bella, C.M.; Jobbágy, E.G.; Paruelo J.M.; Pinnock, S. Continental fire density patterns in South America. Glob. Ecol. Biogeogr. 2006, 15, 192-199.

21. Uhl, C.; Kauffman, J.B. Deforestation, fire susceptibility, and potential tree responses to fire in Eastern Amazon. Ecology 1990, 71, 437-449.

22. Ratter, J.A. Transitions between Cerrado and Forest Vegetation in Brazil. In Nature and Dynamics of Forest-Savanna Boundaries; Chapman and Hall: New York, NY, USA, 1992; p. 616.

23. Kauffman, J.B.; Sanford, JR.; Cummings, D.L.; Salcedo, I.H.; Sampaio, E.V.S.B. Biomass and nutrients dynamics associated with slash fires in neotropical dry forests. Ecology 1993, 74, 140-151.

24. Ratter, J.A.; Ribeiro, J.F.; Bridgewater, S. The brazilian cerrado vegetation and threats to its biodiversity. Ann. Bot. 1997, 80, 223-230.

25. Silva, F.A.M.; Assad, E.D.; Evangelista, B.A. Caracterização Climática do Bioma Cerrado. In Cerrado: Ecologia e Flora, 1st ed.; Sano, S.M., Almeida, S.P., Ribeiro, J.F., Eds.; Embrapa Informação Tecnológica: Brasília, Brazil, 2008; pp. 69-88.

26. França, H.; Setzer, A.W. AVHRR analysis of a savana site through a fire season in Brazil. Int. J. Remote Sens. 2001, 22, 2449-2461.

27. Coutinho, L.M. O conceito de bioma. Acta Bot. Braz. 2006, 20, 13-23.

28. Klink, A.C.; Machado, R.B. A conservação do Cerrado brasileiro. Megadiversidade 2005, 1, $147-155$.

29. Certini, G. Effects of fire on properties of forest soils: A review. Oecologia 2005, 143, doi:10.1007/s00442-004-1788-8.

30. Ministério do Meio Ambiente/SBF. Mapeamento da Cobertura Vegetal do Bioma Cerrado, Relatório Final; Edital Probio 02/2004; Projeto Executivo B.02.02.109, Brasília, Brazil, 2007.

31. Rivera-Lombardi, R.J. Estimativa de Áreas Queimadas com Produtos MODIS como Subsídio à Estimativa de Emissões de Gases de Efeito Estufa pela Queima de Biomassa na Amazônia e Cerrado Brasileiros. Ph.D. Dissertation, Instituto Nacional de Pesquisas Espaciais (INPE), São José dos Campos, Brazil, 2009.

32. Boschetti, L.; Roy, D.; Hoffmann, A.A. MODIS Collection 5 Burned Area Product-MCD45 User's Guide; Version 2.0; University of Maryland: College Park, MD, USA, 2009. 
33. United States Geological Survey (USGS). MODIS Reprojection Tool V4.1; 2011. Available online: http://lpdaac.usgs.gov/lpdaac/tools/ (accessed on 28 June 2011).

34. Boschetti, L.; Roy, D.; Barbosa, P.; Boca, R.; Justice, C. A MODIS assessment of the summer 2007 extent burned in Greece. Int. J. Remote Sens. 2008, 29, 2433-2436.

35. Roy, D.P.; Boschetti, L. Southern Africa Validation of the MODIS, L3JRC and GlobCarbon Burned Area Products. IEEE Trans. Geosci. Remote Sens. 2009, 47, 1032-1044.

36. Justice, C.O.; Giglio, L.; Boschetti, L.; Roy, D.P.; Csiszar, I.; Morisette, J.; Kaufman, Y. MODIS Fire Products-Algorithm Technical Background Document, Version 2.3; October 2006. Available online: http://modis.gsfc.nasa.gov/data/atbd/atbd_mod14.pdf (accessed on 17 January 2012).

37. Kummerow, C.; Simpson, J.; Thiele, O.; Barnes, W.; Chang, A.T.C.; Stocker, E.; Adler, R.F.; Hou, A.; Kakar, R.; Wentz, F.; et al. The status of the tropical rainfall measuring mission (TRMM) after two years in orbit. J. Appl. Meteorol. 2000, 39, 1965-1982.

38. NASA. Monthly $0.25 \times 0.25$ TRMM and Other Sources Rainfall; NASA Distributed Active Archive Center, Goddard Space Flight Center Earth Science: Greenbelt, MD, USA, 2009. Available online: http://disc.sci.gsfc.nasa.gov/precipitation/ (accessed on 20 December 2011).

39. Armenteras-Pascual, D.; Retana-Alumbreros, J.; Molowny-Horas, R.; Roman-Cuesta, R.M.; Gonzalez-Alonso, F.; Morales-Rivas, M. Characterising fire spatial pattern interactions with climate and vegetation in Colombia. Agric. For. Meteorol. 2011, 151, 279-289.

40. Barbosa, H.A.; Huete, A.R.; Baethgen, W.E. A 20-year study of NDVI variability over the Northeast Region of Brazil. J. Arid Environ. 2006, 67, 288-307.

41. World Metereological Organization. WMO statement on the status of the global climate in 2010 . World Meteorol. 2011, 1074, 20.

42. Cardozo, F.S.; Lima, A.; Pereira, G.; Silva, F.B.; Shimabukuro, Y.E.; Takeda, M.M.G.; Moraes, E.C. Avaliação das Imagens do Produto MCD45 do Sensor MODIS Para a Identificação de Áreas Queimadas. In Proceedings of 15th Brazilian Symposium on Remote Sensing (SBSR), Curitiba, Brazil, 30 April-5 May 5 2011; pp. 7942-7949.

43. Giglio, L.; Csiszar, I.; Justice, C.O. Global distribution and seasonality of active fires as observed with the Terra and Aqua Moderate Resolution Imaging Spectroradiometer (MODIS) sensors. J. Geom. Phys. 2006, 111, doi:10.1029/2005JG000142.

44. Giglio, L.; Descloitres, J.; Justice, C.O.; Kaufman, Y.J. An enhanced contextual fire detection algorithm for MODIS. Remote Sens. Environ. 2003, 87, 273-282.

45. NOAA's El Niño Page. February 2012. Available online: http://www.elnino.noaa.gov/ (accessed on 15 February 2012).

46. Marengo, J.A.; Oliveira, G.S. Impactos do Fenômeno La Niña no Tempo e Clima do Brasil: Desenvolvimento e Intensificação do La Niña 1998/1999. In Proceedings of 10th Brazilian Congresso of Meteorology, Brasilia, Brazil, October 1998; [CD-ROM].

47. Marengo, J.A.; Nobre, C.A.; Tomasella, J. The Drought of Amazonia in 2005. Am. Meteorol. Soc. 2008, 21, 1-6.

48. Malhi, Y.; Roberts, J.T.; Betts, R.A.; Killeen, T.J.; Nobre, C.A. Climate change, deforestation and the fate of the Amazon. Science 2008, 19, 169-172. 
49. Lewis, S.L.; Brando, P.M.; Phillips, O.L.; van der Heijden, G.M.F.; Nepstad, D. The 2010 Amazon drought. Science 2011, 331, doi:10.1126/science.1200807.

50. Miranda, H.S.; Sato, M.N.; Andrade, S.M.A.; Harudasan, M.; Morais, H.C. Queimadas de Cerrado: Caracterização e Impactos. In Cerrado: Ecologia e Caracterização; Aguiar, L.M.S., Camargo, A.J.A., Eds.; Embrapa Cerrados: Planaltina, Brazil, 2004; pp. 69-123.

51. Ayoade, J.O. Introdução a Climatologia Para os Trópicos, 9th ed.; Rio de Janeiro: Bertrand, Brazil, 2003; p. 322.

52. Mendonça, F.; Danni-Oliveira, I.M. Climatologia: Noções Básicas e Climas do Brasil, 1st ed.; Oficina de textos: São Paulo, Brazil, 2007; p. 208.

53. Uhl, C.; Buschbacher, R.; Serrão, E.A.S. Abandoned pastures in Eastern Amazonia. I. Patterns of plant succession. J. Ecol. 1988, 76, 663-681.

54. Kauffman, J. B; Cummings, D. L; Ward, D.E. Fire in the Brazilian Amazon 2. Biomass, nutrient pools, and losses in cattle pastures. Oecologia 1998, 113, 415-427.

55. Davidson, E.A.; Neill, C.; Krusch, A.V.; Ballester, V.V.R.; Markewitz, D.; Figueiredo, R.O. Loss of Nutrients from Terrestrial Ecosystems to Streams and the Atmosphere Following Land Use Change in Amazonia. In Ecosystems and Land Use Change; DeFries, R., Asner, G., Houghton, R., Eds.; American Geophysical Union: Washington, DC, USA, 2004, pp. 147-158.

56. Krug, T.; Rivera-Lombardi, R.J.; Dos Santos, J.R. Burned area, Recurrence of Fires and Permanence of Burnt scars in Selected Areas of the Brazilian Cerrado Using TM-Landsat Imagery. In Proceedings of the XXth ISPRS Congress: Geo-Imagery Bridging Continents, Istanbul, Turkey, 12-23 July 2004; pp. 243-246.

57. Ramos-Neto, M.B.; Pivello, V.R. Lightning fires in a Brazilian savanna National Park: Rethinking management strategies. Environ. Manag. 2000, 26, 675-684.

58. Pivello, V.R. Fire Management for Biological Conservation in the Brazilian Cerrado. In Savana and Dry Forests-Linking People with Nature; Mistry, J., Berardi, A., Eds.; Ashgate: Farnham, UK, 2006; pp. 129-154.

59. Morton, D.C. Changes in Amazon Forest Structure from Land-Use Fires: Integrating Satellite Remote Sensing and Ecosystem Modeling. Ph.D. Dissertation, University of Maryland, College Park, MD, USA, 2008.

60. Cardoso, M.F.; Nobre, C.A.; Sampaio, G.; Hirota, M.; Valeriano, D.; Câmara, G. Long-term potential for tropical-forest degradation due to deforestation and fires in the Brazilian Amazon. Biologia 2009, 64, 433-437.

61. Ferreira, L.G.; Ferreira, M.E.; Rocha, G.F.; Nemayer, M.; Ferreira, N.C. Dinâmica agrícola e desmatamentos em áreas de Cerrado: Uma analise a partir de dados censitários e imagens de resolução moderada. Rev. Bras. Cartogr. 2009, 61, 117-127.

62. Rocha, G.F.; Ferreira JR. L.G.; Ferreira, N.C.; Ferreira, M.E. Detecção de desmatamentos no bioma Cerrado entre 2002 e 2009: Padrões, tendências e impactos. Rev. Bras. Cartogr. 2011, 63, 341-349.

63. Diniz-Filho, J.A.F.; Oliveira, G.; Lobo, F.; Ferreira, L.G., Jr.; Bini, L.M.; Rangel, T.F.V.L.B. Agriculture, habitat loss and spatial patterns of human occupation in a biodiversity hotspot. Sci. Agric. 2009, 66, 764-771. 
64. Jepson, W. A disappearing biome? Reconsidering land cover change in the Brazilian savanna. Geogr. J. 2005, 17, 99-111.

65. Pivello, V.R.; Coutinho, L.M. Tranfer of macro-nutrients to the atmosphere during experimental burnings in a open cerrado (Brasilian savanna). J. Trop. Ecol. 1992, 8, 457-497.

66. Pivello, V.R.; Coutinho, L.M. A qualitative successional model to assist in the management of Brazilian cerrados. For. Ecol. Manag. 1996, 87, 127-138.

67. Nepstad, D.C.; Moreira, A.G.; Alencar, A.A. Floresta em Chamas: Origens, Impactos $e$ Prevenção do Fogo na Amazônia; Programa Piloto para Proteção das Florestas Tropicais do Brasil: Brasília, Brasil, 1999; p. 202.

68. Morton, D.C.; Shimabukuro, Y.E.; Rudorff, B.F.T.; Lima, A. ; Freitas, R.M.; DeFries, R.S. Conservation challenge at the agricultural frontier: Deforestation, fire, and land use dynamics in Mato Grosso. Ambi-Agua 2007, 2, 5-20.

69. Ferreira, L.V.; Venticinque, E.; Almeida, S. O desmatamento na Amazônia e a importância das áreas protegidas. Estud. Avançad. 2005, 19, 1-10.

70. Fearnside, P.M. Desmatamento na Amazônia brasileira: História, índices e conseqüências. Megadiversidade 2005, 1, 113-123.

71. Nogueira, E.M.; Fearnside, P.M.; Nelson, B.W.; Franca, M.B. Wood density in forests of Brazil's "arc of deforestation": Implications for biomass and flux of carbon from land-use change in Amazonia. For. Ecol. Manag. 2007, 248, 119-135.

72. Silvestrini, R.A.; Soares-Filho, B.S.; Nepstad, D.; Coe, M.; Rodrigues, H.O.; Assunção, R. Simulating fire regimes in the Amazon in response to climate change and deforestation. Ecol. Appl. 2011, 21, 1573-1590.

73. Costa, M.H.; Pires, G.F. Effects of Amazon and Central Brazil deforestation scenarios on the duration of the dry season in the arc of deforestation. Int. J. Climatol. 2010, 30, 1970-1979.

74. Lara, L.L.; Artaxo, P.; Martinelli, L.A.; Victoria, R.L.; Ferraz E.S.B. Properties of aerosols from sugar-cane burning emissions in Southeastern Brazil. Atmos. Environ. 2005, 39, 4627-4637.

75. Carvalho, J.L.N.; Avanzi, J.C.; Silva, M.L.N.; Mello, C.R.; Cerri, C.E.P. Potencial de sequestro de carbono em diferentes biomas do Brasil. Rev. Bras. Ciênc. Solo 2010, 34, 277-289.

76. Ribeiro, H.; Ficarelli, T.R.A. Queimadas nos canaviais e perspectivas dos cortadores de cana-de-açúcar em Macatuba, São Paulo. Saúde Soc. 2010, 19, 48-63.

77. Rudorff, B.F.T.; Aguiar, D.A.; Silva, W.F.;Sugawara, L.M.; Adami, M.; Moreira, M.A. Studies on the rapid expansion of sugarcane fo ethanol production in São Paulo (Brazil) using Landsat data. Remote Sens. 2010, 2, 1057-1076.

78. Aguiar, D.A.; Silva, W.F.; Rudorff, B.F.T.; Adami, M. CANASAT Project: Monitoring the Sugarcane Harvest Type in the State of São Paulo, Brazil. In Proceedings of the International Archives of the Photogrammetry, Remote Sensing and Spatial Information Sciences (ISPRS) TC VII Symposium -100 Years ISPRS, Vienna, Austria, 5-7 July 2010; Volume 38, pp. 10-15.

(C) 2012 by the authors; licensee MDPI, Basel, Switzerland. This article is an open access article distributed under the terms and conditions of the Creative Commons Attribution license (http://creativecommons.org/licenses/by/3.0/). 